\title{
Observations on the distribution and biology of Huffmanela huffmani (Nematoda: Trichosomoididae)
}

\author{
Marlin K. Cox ${ }^{1}$, David G. Huffman ${ }^{2}$ and František Moravec ${ }^{3}$ \\ ${ }^{1}$ Department of Fisheries, Percival Hall, West Virginia University, Morgantown, West Virginia 26505, USA; \\ ${ }^{2}$ Aquatic Biology, Southwest Texas State University, San Marcos, Texas 78666, USA; \\ ${ }^{3}$ Institute of Parasitology, Academy of Sciences of the Czech Republic, Branišovská 31, 37005 České Budějovice, Czech \\ Republic
}

Key words: Nematoda, Trichosomoididae, Huffmanela, geographic distribution, life cycle

\begin{abstract}
The nematode parasite Huffmanela huffmani Moravec, 1987 (Trichosomoididae) infects swimbladders of fishes in the family Centrarchidae. Only fish collected from the upper San Marcos River (Texas) have been found infected with $H$. huffmani eggs with a prevalence of $90 \%$. Hundreds of thousands of $H$. huffmani eggs have been observed in these fish but only a few specimens of adult worms have ever been found. The San Marcos River arises from springs along the Balcones Fault Zone in San Marcos, Hays County, Texas. The restriction of the parasite to the upper San Marcos River and the high prevalence of the parasite eggs in centrarchids would seem to enable one to solve the life cycle of $H$. huffmani but this has proved false. Here, the insights and experiments used to help define some of the aspects concerning the life cycle of this enigmatic parasite are described. This study of $H$. huffmani includes a description of the habitat, the known limits of geographic distribution of the parasite, possible dispersal processes, egg characteristics, the testing of a possible intermediate host, Palaemonetes antrorum (Benedict) (Decapoda: Palaemonidae), and the effects of the digestion process on H. huffmani eggs.
\end{abstract}

The swimbladder nematode Huffmanela huffmani Moravec, 1987 (Trichinelloidea, Trichosomoididae) is the only species of the genus known to parasitize freshwater fishes and the only one in which adult nematodes have been described (Huffman and Moravec 1988). Congeneric species are known by their eggs only (Moravec et al. 1998). The distribution of H. huffmani seems to be restricted to the upper San Marcos River in Central Texas, USA. Although approximately $90 \%$ of centrarchid fishes have been found to harbour $H$. huffmani eggs within their swimbladders, only a few adults of the species have ever been recorded (Michel 1984, Huffman and Moravec 1988).

There has been speculation that one of the endemic animals restricted to the upper San Marcos River may be required in the unknown life cycle of $H$. huffmani. Attempts to infect sunfish with invertebrates suspected of possibly being intermediate hosts of $H$. huffmani have been unsuccessful (Michel 1984, who identified the worm as Capillaria sp.). Currently, the life cycle of H. huffmani is still unknown, and gaps in the knowledge of other aspects of the biology of this remarkable parasite make defining the life cycle difficult.

The present paper gives some new data on the distribution and biology of $H$. huffmani based on field observations and experiments carried out at Southwest Texas State University in San Marcos, Texas in 1997.

\section{MATERIALS AND METHODS}

The study sites were all located in the South-Central Texas region (Fig. 1) where the water source for several springs, creeks, and rivers is the Edwards Aquifer, a large, rainfallrecharged aquifer. Most of the studies were carried out on the San Marcos River, which arises from springs along the Balcones Fault Zone in San Marcos, Hays County, Texas. A few hundred metres downstream from the headsprings, a dam forms an 18 ha impoundment known as Spring Lake (Fig. 2). The lake consists of a main body of water that contains numerous springs along the thalwag, and a slough area formed by inundation of the mouth of Sink Creek. The slough does not contain headsprings and enters the lake $75 \mathrm{~m}$ downstream from the main springs on the northeast side of the lake. From there it extends north-east for $600 \mathrm{~m}$ into Aquarena Springs golf course where it becomes shallow and turbid. Below the dam, the river continues on through the city of San Marcos. It receives surface water from three intermittent creeks (Sessom, Willow, and Purgatory creeks), several storm sewers, and one wastewater treatment plant before it reaches the confluence with the Blanco River $6.4 \mathrm{~km}$ downstream.

The species of sunfish that were examined during the field studies included: Lepomis auritus (Linnaeus), L. cyanellus Rafinesque and L. macrochirus Rafinesque; all of them have been reported as the hosts of $H$. huffmani (see Huffman and Moravec 1988). For vertical distribution studies, 20 sunfish (Lepomis spp.) were collected from Spring Lake at two sites; Kettlemans, and the Ossified Forest. The fish were collected from three different depths at both sites: shallow (near the 
surface), medium (half the distance to the bottom), and bottom. For horizontal distribution studies (Fig. 2), 21 sunfish were collected just below Spring Lake dam, from along the shore and from the middle of the river. Additionally, 19 sunfish were collected at each of four sites within Spring Lake (Fig. 2): 1) four from directly over the head springs in the main body of the lake, 2) seven from along the east shoreline of the lake, 3) four from $100 \mathrm{~m}$ up the slough along the shore, and 4) four from $500 \mathrm{~m}$ up the slough along the shore. In order to investigate the downstream range of the parasite, five sites were chosen along the San Marcos River from Sewell Park to Thompson's Island and eight fish were collected from each site. In order to determine if the geographic range of $H$. huffmani might extend beyond the upper San Marcos River, 66 sunfish were collected from four other surface waters that receive flow from the Edwards Aquifer: Landa Lake in New Braunfels (Comal County), Jacobs Well in Wimberly (Hays County), Barton Springs in Austin (Travis County), and the Blanco River (Hays County).

In an attempt to determine the normal anatomical location of adult $H$. huffmani, six sunfish (Lepomis auritus) collected from the upper San Marcos River were examined in detail, including a thorough examination of the epidermis, muscles, and internal organs (especially kidneys and surrounding renal arteries). The three layers of the swimbladder (lamina epithelia, muscularis, and serosa) were examined using the method described by Anderson and Mitchum (1974). The morphology of $H$. huffmani eggs was examined by both light (LM) and scanning electron microscopy (SEM). Eggs were counted using a dissecting microscope with an ocular micrometer. The number of eggs on a $0.1 \mathrm{~mm}^{2}$ section of swimbladder was multiplied by the swimbladder surface area to estimate the egg count for each fish, and the mean number of eggs estimated for four fish was used for the reported egg count. Cable's (1977) digestion method was used to liberate the eggs from swimbladder tissue, and the viability of eggs was determined by compressing eggs between a slide and cover slip thereby expressing the egg contents.

Several experiments designed to investigate the life cycle of $H$. huffmani were carried out. Five largemouth bass, Micropterus salmoides (Lacépède), were fed three sunfish collected from the upper San Marcos River every 2 weeks for a period of 20 weeks to determine if $M$. salmoides might act as a paratenic or transport host for $H$. huffmani eggs. For 3 weeks, 30 uninfected sunfish (Lepomis macrochirus) were fed benthic macroinvertebrates collected from the upper San Marcos River to screen for possible intermediate hosts of $H$. huffmani. Twenty tropholitic cave shrimp, Palaemonetes antrorum (Benedict) (Decapoda: Palaemonidae), collected from the artesian well in San Marcos were fed to each of three uninfected sunfish to test the possibility of shrimp emerging directly from the aquifer infecting the fish with $H$. huffmani. These fish were examined 3 weeks later. To determine if cave shrimp can ingest $H$. huffmani eggs, ten shrimp were placed in each of two 1-litre containers, one containing viable $H$. huffmani eggs in largemouth bass faeces, the other with macerated, egg-laden, sunfish swimbladders. The cave shrimp stomachs were examined for the presence of $H$. huffmani eggs 4 days later.

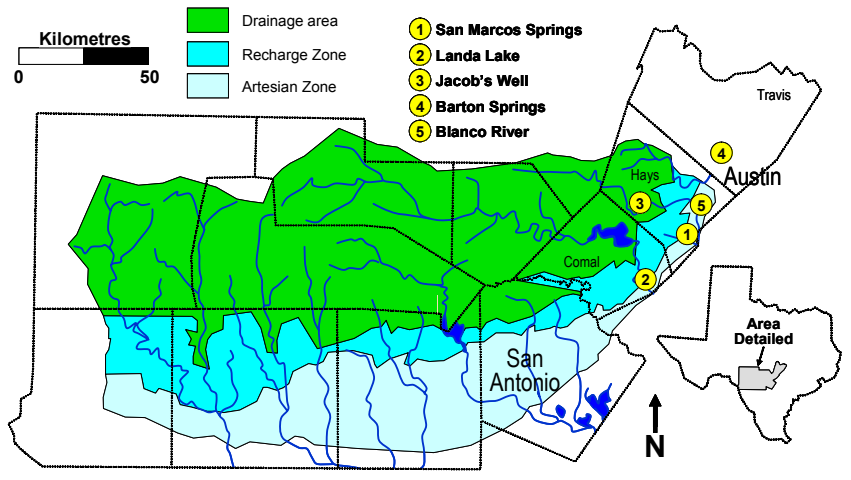

Fig. 1. Map of South Central Texas showing aquifer discharge sites. (Source: USGS.)

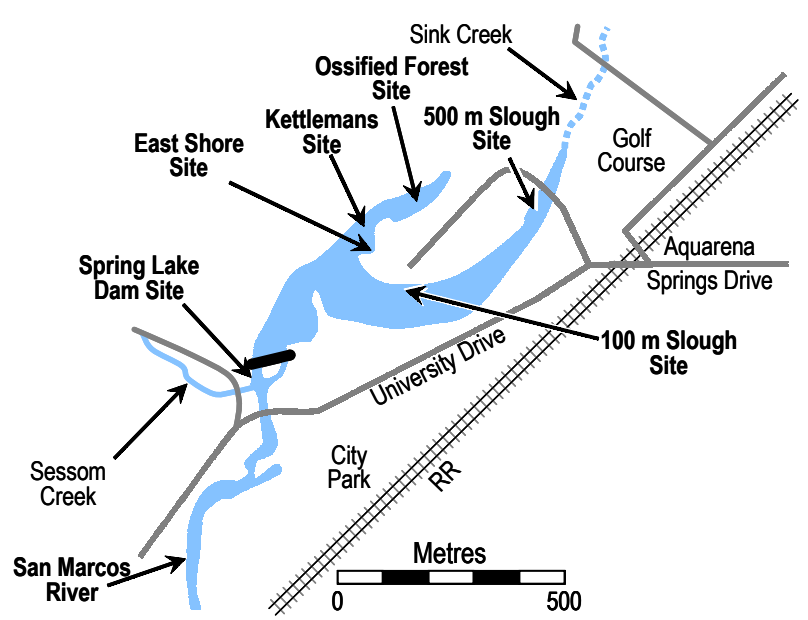

Fig. 2. Map of Spring Lake showing the location of the headsprings and four collecting sites.

\section{RESULTS}

\section{Distribution}

Vertical. Out of 20 sunfish examined from different depths within Spring Lake, 100\% were infected with Huffmanela huffmani. There were no apparent associations between species of sunfish, depth of collection, and degree of infection.

Horizontal. Out of 19 fish collected from Spring Lake, $11(57 \%)$ were infected with $H$. huffmani. All four of the sunfish collected from the main body of water had heavy infections. None of the seven fish collected along the east bank of the lake were infected. Out of four fish collected $100 \mathrm{~m}$ up the slough, one was infected. None of the four fish collected $500 \mathrm{~m}$ up the slough were infected.

Downstream. Nine sunfish were collected along the shore of the San Marcos River below Spring Lake dam and all were infected with $H$. huffmani, including two with light infections, one with a medium infection and 


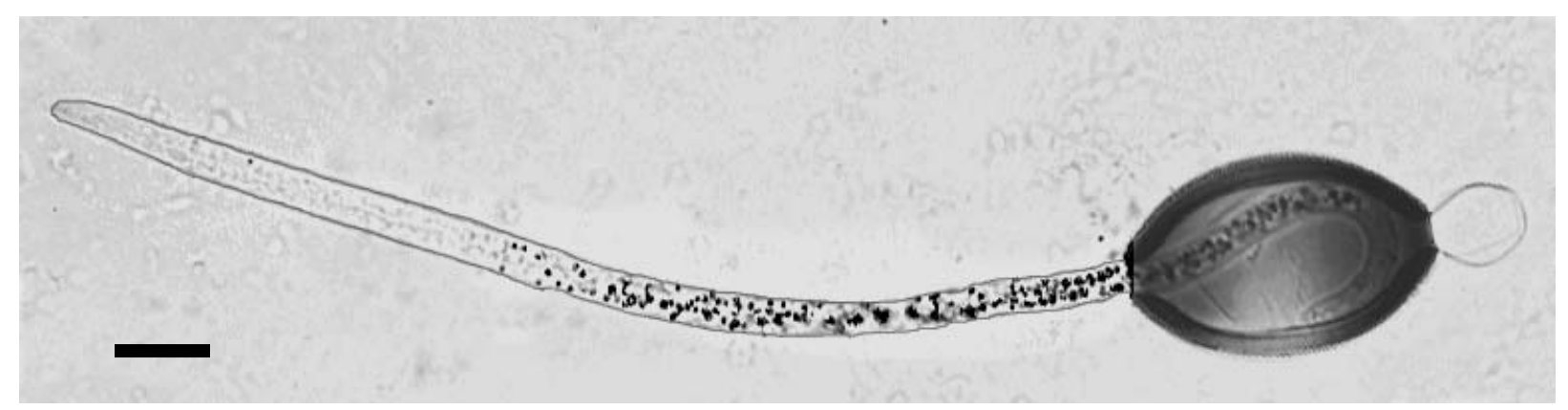

Fig. 3. Huffmanela huffmani, hatching larva. Photomicrograph. Scale bar $=15 \mu \mathrm{m}$.

six with heavy infections. Out of 12 fish collected from the middle of the river, nine $(74 \%)$ were infected, including two with light infections, one with a medium infection and six with heavy infections.

Geographic. No sunfish were found infected with $H$. huffmani at any of the collection sites other than from the San Marcos River.

\section{Location in definitive host}

The $H$. huffmani eggs were always found located in the serosa (innermost layer) of the host's swimbladder. Most were located in clumps on the ventral part of the swimbladder, but some were also arranged in a rib-like series of vertical bars on the sides of the swimbladder.

\section{Egg studies}

Egg morphology. Light and scanning electron microscopy observations of $H$. huffmani eggs within swimbladders of sunfish were consistent with the illustrations provided by Moravec (1987) and by Huffman and Moravec (1988). The typical fully developed egg contained a larva $240 \mu \mathrm{m}$ long (Fig. 3).

Egg count. The mean size of four medium-infected swimbladders examined for egg counts was $26 \times 26 \mathrm{~mm}$ $\left(676 \mathrm{~mm}^{2}\right)$. The egg count estimate was 662 eggs per $\mathrm{mm}^{2}$, or 447,512 eggs for a medium-sized, mediuminfected sunfish.

Egg viability. The sunfish swimbladders were totally digested on day 2 , and the eggs of $H$. huffmani were observed to be at various stages of development. After 3 weeks, the eggs from the fish swimbladders, as well as those from the artificial gastric juice contained larvae that could be seen moving inside the shells. While photographing the egg, one of the eggs hatched and the larva was photographed and measured (Fig. 3). Twenty minutes later, a total of four eggs had hatched and the larvae were seen swimming through the water. That same day, eggs that had been in a beaker of artesian well water for 4 months were pipetted and two eggs were observed hatching.

\section{Life cycle studies}

Processing of eggs by largemouth bass. Three of the five largemouth bass died before the sunfish were consumed, and subsequently were replaced by three more largemouth bass. Post-feeding examination of the bass faecal content showed numerous intact $H$. huffmani eggs. The eggs always seemed to be embedded in a grey faecal mass. The eggs collected in January were found to contain moving larvae inside the eggs. None of the swimbladders of the five largemouth bass dissected over a 5-month period were infected with $H$. huffmani.

Attempts to infect sunfish. All experiments in which sunfish had been fed various invertebrates from the upper San Marcos River yielded negative results.

Shrimp from aquifer as a possible infection source. No $H$. huffmani were found in the sunfish that had been fed cave shrimp from the artesian well after the 3-week incubation period.

Ingestion of eggs by cave shrimp. Out of ten cave shrimp feeding on the faeces of largemouth bass, two shrimp had ingested a total of five $H$. huffmani eggs. Out of ten cave shrimp that had been feeding on macerated swimbladders, five had ingested 11 eggs.

In one experiment, 12 cave shrimp originating from the artesian well were placed in a $500-\mathrm{ml}$ beaker of aerated well water. More than 1 million $H$. huffmani eggs from sunfish swimbladders were added. All cave shrimp had died by day 5 and their bodies, including the gills, were covered with thousands of $H$. huffmani eggs. Out of these 12 shrimp, two contained a total of five intact $H$. huffmani eggs in their gut. No hatched larvae were found in any of the shrimp.

\section{DISCUSSION}

Our distributional studies suggest that Huffmanela huffmani is restricted to the upper San Marcos River. The fact that it has not been found anywhere else in the Edwards Aquifer region suggests that the aquifer is not harbouring infective stages of the parasite. The upper San Marcos River harbours H. huffmani, but $6.4 \mathrm{~km}$ downstream at its confluence with the Blanco River, $H$. huffmani is not found. This suggests that the geographic distribution of $H$. huffmani is associated with some aspects of the various headwater springs. The water characteristics downstream may be influencing the range of $H$. huffmani, or the distance from the springs may be an influencing factor. The distribution of $H$. 
huffmani in Spring Lake suggests that an intermediate host closely associated with the springs is required in the life cycle of $H$. huffmani. If this intermediate host is closely associated with or even discharged from the springs, then one would expect to find the observed decrease in its population density downstream from the springs.

The eggs of $H$. huffmani have been found in the swimbladders of sunfish, but few adults have so far been observed (Huffman and Moravec 1988). In this study, no adults were observed.

All eggs were found to be imbedded in the tissues of the serosa (innermost layer) of the swimbladder, suggesting that the adults, at least the females, are histozoic. There was a distinct pattern in the overall placement of eggs, which may indicate some association between the eggs and the vasculature of the swimbladder. The serosa is a highly vascularized site and the possibility of eggs being transported from some remote site to the swimbladder via the bloodstream and forming such a pattern should be considered. However, dissection of tissues upstream from the swimbladder did not reveal adults, and all adults found thus far in other studies have been in the serosa.

The LM and SEM studies of $H$. huffmani eggs confirmed egg morphology of the species published by Huffman and Moravec (1988). The results from the egg development study show that the eggs develop from an early stage to an advanced stage in 7-30 days. The advanced eggs contained a larva, but there was no evidence that a moult had taken place inside the egg shell. Bird (1971) found that the chemical composition of the egg shells of many different species of nematodes contain a quinone that may occur in many layers of the egg cuticle (including the chitinous layer) and that quinone turns a dark colour when oxidized. So the darkening of the shell of $H$. huffmani eggs may represent the oxidizing of the quinone in the egg rather than the development of the larva.

Over 500,000 eggs were estimated to be on a medium-infected, medium-sized sunfish. On a large, heavy infected sunfish there could be upwards of a million eggs. Some nematodes lay up to 200,000 eggs per day (Chandler 1932), but female nematodes of the family Trichuridae only lay 5,000-10,000 eggs per day (Otto 1958). The high number of eggs per swimbladder, the experimental estimates of 30 days for egg development, the varying degree of egg development throughout the year, and the rarity of observed adults all suggest that there must be multiple, short-lived $H$. huffmani females laying eggs throughout the year.

Both experiments involving the feeding of invertebrates from the San Marcos River or artesian well to sunfish yielded negative results. In the first case the negative results may be attributed to the short incubation time ( 3 weeks). The second case (duration 15 months) indicates that the infection was definitely not coming from the invertebrates collected directly from the aquifer.

It has been experimentally demonstrated in this study that the largemouth bass is a disseminator of millions of larvated $H$. huffmani eggs into the water via its faeces. Largemouth bass feeding on infected sunfish did not themselves become infected and therefore infection is probably not transferred between fish. However, Underwood (1981) and Michel (1984) found bass swimbladders to occasionally contain eggs. This would indicate that the bass are also eating the same intermediate host as the sunfish, but probably when they were young.

The results of this study seem to indicate that there is an intermediate host involved in the life cycle of $H$. huffmani that limits the geographical distribution of the parasite. The intermediate host should also have a geographic range similar to that of $H$. huffmani in the San Marcos River. Since the cave shrimps, Palaemonetes antrorum and P. kadiakensis Rathbun, may have downstream ranges that are similar to $H$. huffmani, and because $P$. antrorum was found to be able to ingest $H$. huffmani eggs, it is possible that these shrimps may serve as the intermediate host for $H$. huffmani.

Acknowledgements. We would like to thank Bobby Whiteside and Donald Tuff, Aquatic Biology, Southwest Texas State University, for their constructive assistance in reviewing this manuscript. Thanks are also due to the former graduate students of the same University, especially Brain Cook, Chad Thomas, Thorpe Halloran, John Burch and the late Strider Aragorn, for their support and help during this project. The work was partly supported from the grant no. A6022201 from the Grant Agency of the Academy of Sciences of the Czech Republic.

\section{REFERENCES}

ANDERSON B.G., MITCHUM D.M. 1974: Atlas of Trout Histology. Wyoming Game and Fish Department, Wyoming, Bull. 13, 110 pp.

BIRD A.F. 1971: The Structure of Nematodes. Academic Press, New York, 317 pp.

CABLE R.M. 1977: An Illustrated Laboratory Manual of Parasitology. Burgess Publishing Company, Minneapolis, Minnesota, $274 \mathrm{pp}$.
CHANDLER A.C. 1932: Susceptibility and resistance to helminthic infections. J. Parasitol. 18: 135.

HUFFMAN D.G., MORAVEC F. 1988: First description of adult Huffmanela huffmani Moravec, 1987 (Nematoda: Trichosomoididae) from the swimbladder of centrarchid fishes of the upper San Marcos River, Central Texas. Folia Parasitol. 35: 227-234. 
MICHEL G.D. 1984: The biology of Capillaria sp. (Nematoda: Capillariidae) from swim bladders of sunfishes of the upper San Marcos River. M.S. thesis, Southwest Texas State University, San Marcos, Texas, 59 pp.

MORAVEC F. 1987: Revision of Capillariid Nematodes (Subfamily Capillariinae) Parasitic in Fishes. Studie ČSAV No. 3. Academia, Praha, 141 pp.

MORAVEC F., KOUDELA B., OGAWA K., NAGASAWA

K. 1998: Two new Huffmanela species, H. japonica $\mathrm{n}$. sp.

Received 11 August 2003 and H. shikokuensis $\mathrm{n}$. sp. (Nematoda: Trichosomoididae), from marine fishes in Japan. J. Parasitol. 84: 589-593.

OTTO G.F. 1958: Some reflections on the ecology of parasitism. J. Parasitol. 44: 1-27.

UNDERWOOD H.T. 1981: Ecological studies on the endohelminth fauna of fishes from the upper San Marcos River. College Station: Texas A\&M University Dissertation, 328 pp.

Accepted 17 December 2003 